\title{
Milk Composition and Quality of Sahiwal - Friesian Crossbred Cow Studied in Malaysia
}

\author{
M. A. I. Talukder ${ }^{1 *}$, J. M. Panandam², Y. Halimatun² and I. Idris ${ }^{2}$ \\ ${ }^{1}$ GSDR Division, Bangladesh Livestock Research Institute, Savar, Dhaka-1341, Bangladesh \\ ${ }^{2}$ Department of Animal Science, Universiti Putra Malaysia, 43400 UPM, Serdang, Selangor, \\ Malaysia \\ *Corresponding author and Email: talukder1963@yahoo.com
}

Received: 22 November 2012

Accepted: 06 December 2013

\begin{abstract}
Six groups of Sahiwal-Friesian crossbred cows, namely M50-1, M50-2, M50-3, M56, M63 and M75-1 were evaluated. In total 180 cows were used and milk collected was evaluated for composition and quality. The effect of genotypes was significant $(P \leq 0.05)$ only for titrable acidity (TA) and milk yield (MY). The M50-1 had the highest milk yield per day $(8.73 \pm 1.65 \mathrm{~kg})$ but this was not significantly different from the yields of M50-3, M56 and M75-1 (7.06 $\pm 0.84,7.06 \pm 0.96,7.70 \pm 0.82 \mathrm{~kg})$, respectively. Lactation stage had significant $(P \leq 0.05)$ effect on milk yield, fat content, solids-not fat (SNF) content, total solid (TS) content, moisture content and specific gravity (Sp. Gr). Fat content at early lactation was significantly $(P \leq 0.01)$ lower than at middle and late lactation (3.69 vs 4.27 and 4.50, respectively). SNF content for middle lactation was significantly lower $(P \leq 0.05)$ than that at early and late lactations. At late lactation, TS and moisture contents were significantly $(P \leq 0.05)$ higher than those at early lactation. The range of milk composition and quality such as fat $(3.96-4.50 \%)$, SNF (9.02 - 9.40\%), TS (13.01-13.81\%), moisture (86.26 - 87.07\%), Sp.Gr. (1.030- 1.031), pH (6.74 6.91), TA (0.13-0.15\%), MBRT (6.50 -7.40 h) belonged to normal range. M50-1, M50-3, M56 and M75-1 had higher test day milk yield. The optimum level of Friesian inheritance in combination with Sahiwal for MY appeared to be $75 \%, 56 \%$ and $50 \%$ with selection for milk production. The composition and quality of milk from the Sahiwal - Friesian crossbred cows met the required standard.
\end{abstract}

Keywords: Milk composition, quality, Sahiwal - Friesian, crossbred

\section{Introduction}

The self- sufficiency for milk in Malaysia is only $4.5 \%$ (DVS, 1998). The dairy market in Malaysia is mainly dependent on imported milk and milk products. The import of dairy products leads to loss of foreign exchange. The demand for livestock products as a source of high quality protein is expected to continue to rise with the increasing population and per capita income, consistent with the overall rapid development of the country. In order to realise these targets, the government embarked on a crossbreding programmed involving the Sahiwal and Friesian dairy cattle breeds (Osman, 1993). It was expected that with substantial increase in the number of improved dairy cattle, the supply of milk and milk products from local sources would increase.

The Department of Veterinary Services imported a large number of Sahiwal $\times$ Friesian crossbreds 
and purebred Friesians from Australia and New Zealand in 1978 (Sivarajasingam et al., 1982). The crossbreeding programme aimed for grading up crossbreds by continual crossing with Friesian. Crossbreds with 50, 56.25, 62.5 and $75 \%$ Friesian genes have been produced as a result. Studied on milk production of various dairy cattle in Malaysia showed that Sahiwal Friesian crossbred cows had good milking ability, second only M63 crossbred cows (Raymond and Ratnakumar, 1997). The present study was conducted to evaluate milk composition and quality of Sahiwal - Friesian crossbred cows in Malaysia.

\section{Materials and Methods}

Cows from the research farm of the Ladang Pusat Ternakan Haiwan at Ayer Hitam, Johor under the Department of Veterinary Service (DVS), Ministry of Agriculture, Malaysia, were used in this study. The farm was situated approximately 20 meters above sea level at latitude $5^{\circ} \mathrm{N}$ and longitude $102{ }^{\circ} \mathrm{E}$. The farm received an average annual rainfall of $3000 \mathrm{~mm}$, mean monthly temperature ranging from 26 to $39{ }^{\circ} \mathrm{C}$, and average relative humidity of $60 \%$ to $90 \%$ (IHK, 1999).

The cattle production records studied were those between the years 1981 to 2002. They comprised of Sahiwal - Friesian crossbred cows of various percentage of Friesian inheritance. Sahiwal $\times$ Friesian $F_{1}$ crosses were imported from Australia and New Zealand as heifers or as heifer calves (Sivarajasingam and Kumar, 1993). Through inter se mating and crossbreeding, using imported semen and that from selected sires, a number of crossbred groups with Friesian inheritance ranging from 50-75\% were produced.

Milk samples were collected from a sample of the breed group available at the Ladang Pusat Ternakan Haiwan at Ayer Hitam, Johor. Animals were selected on the basis of available breed group and stages of lactation. Thirty lactating cows from each breed group were used. Cows were selected on the basis of their stage of lactation (early lactation: 1-30 days, middle lactation: 110-130 days and late lactation: 290305 days). Ten cows from each stage was studied for each breed group.

Individual milk samples were collected at three different times during the stage of lactation. 250 $\mathrm{ml}$ of milk sample from each cow was collected from morning milk in sterile sampling bottle and immediate by kept in icebox. Before testing the milk sample it was warmed to normal temperature and sample in bottles were shaken gently. Chemical analysis [fat content, solids-not fat (SNF) content, total solid (TS) content, moisture content, specific gravity (Sp. Gr), titrable acidity (TA), methylene blue reduction test (MBRT) and $\mathrm{pH}]$ of the samples was carried out in Milk Collection Centre (MCC) of the Institute Haiwan, Kluang, Johor.

Six crossbreed groups were evaluated. The crossbreed groups M50-1 (Sahiwal $\times$ Friesian $\left.\mathrm{F}_{2}\right)$, M50-2 (Sahiwal $\times$ Friesian $\left.\mathrm{F}_{3}\right)$, M50-3 $\left(\right.$ Sahiwal $\times$ Friesian $\left.\mathrm{F}_{4}\right)$, M56 $($ Sahiwal $\times$ Friesian $45.75 \%$ Sahiwal $\times 56.25 \%$ Friesian $\mathrm{BC}_{3}$ ), M63 $($ Sahiwal $\times$ Friesian, $37.5 \%$ Sahiwal $\times 62.5 \%$ Friesian $\mathrm{BC}_{2}$ ), and M75-1 (Sahiwal $\times$ Friesian, $25 \%$ Sahiwal $\times 75 \%$ Friesian) were evaluated.

The breeding design practiced was continuous upgrading of the Sahiwal - Friesian $F_{1}$ to Holstein. Prior to 1989 , all mating were accomplished by means of artificial insemination (AI) using imported semen of selected sires. Since 1989, the imported semen has been supplemented with semen collected at the National Animal Biotechnology Institute, Jerantut, Pahang. Cows were selected on the basis of their milk production.

The management practice was to keep cows on pasture throughout the day and night except during milking. The pastures were mainly of Brachiaria decumbens (90\%), Panicum maximum and Paspalm sp. The heifer and cows were allowed to graze on pasture at the rate of 1.7 acre /animal. Milking cows were supplied with concentrate palm kernal cake (PKC) before 
milking. Level of feeding was determined on the basis of milk output, approximately $1 \mathrm{~kg}$ concentrate for every $4 \mathrm{~kg}$ of milk produced. The lactating cows were milked twice daily using machines, once in the morning (7.30 a.m.) and again in the afternoon (3.30 p.m.). Each milking was preceded by an udder wash with a clean warm towel. After milking the teats were dipped in iodine solution for prevention of mastitis. Morning and evening milk production were recorded to determine the total milk yield of a cow in a day.

The milk composition and quality tests from a total of 180 animals were analysed. The statistical analysis of the data was performed for analysis of variance model procedure of the Statistical Analysis System (SAS) for Windows 2000 PC software package. The differences between treatment means were examined using Duncan's multiple range test (DMRT).

The data on milk composition were analyzed using the following statistical model:

$\mathrm{Y}_{\mathrm{ijkl}}=\mu+\mathrm{G}_{\mathrm{i}}+\mathrm{L}_{\mathrm{j}}+(\mathrm{G} \times \mathrm{L})_{\mathrm{ij}+} \mathrm{Y}_{\mathrm{k}}+\mathrm{e}_{\mathrm{ijkl}}$

where,

$\mathrm{Y}_{\mathrm{ijk} 1}=$ an observation on milk composition,

$\mu=$ the overall mean,

$\mathrm{G}_{\mathrm{i}}=$ effect of breed group of cow ( $\mathrm{i}=\mathrm{M} 50-1$, M50-2, M50-3, M56, M63, M75-1),

$\mathrm{Lj}=$ effect of the lactation stage $(\mathrm{j}=1-3,1=$ early, $2=$ middle, $3=$ late),
$(\mathrm{G} \times \mathrm{L})_{\mathrm{ij}}=$ effect of interaction between breed group and the lactation stage,

$\mathrm{Y}_{\mathrm{k}}=$ effect of year of calving $(\mathrm{k}=1985$ 2001), and

$\mathrm{e}_{\mathrm{ijkl}}=$ random error, assumed to be normally distributed with mean zero and common variance.

\section{Results and Discussion}

The analyses of variance for the different milk composition and quality test are presented in Tables 1 and 2 . There was no significant interaction between breed group except in MY in milk composition traits (Table 1). All milk composition traits were significantly different with lactation stage.

\subsection{Effect of breed group}

The effect of breed group was significant $(P \leq 0.05)$ only for titrable acidity (TA) and milk yield (MY) (Table 3). M50-1, M50-3, M56 and M75-1 had higher test day milk yield however, they were not significantly different among them (Table 3). Although, Nevens (2010) stated that there was wide variation in the amount of milk produced by cows within a breed. The optimum level of Friesian inheritance in combination with Sahiwal for MY appeared to be $75-1 \%, 56 \%, 50$ $1 \%$ and $50-3 \%$ with selection for milk production.

Table 1. Analysis of variance of milk composition traits

\begin{tabular}{lccccccccccc}
\hline $\begin{array}{l}\text { Source of } \\
\text { Variation }\end{array}$ & DF & \multicolumn{2}{c}{ MY } & \multicolumn{2}{c}{ Fat } & \multicolumn{3}{c}{ SNF } & \multicolumn{2}{c}{ TS } & \multicolumn{2}{c}{ H20 } \\
\cline { 2 - 12 } & & MS & Pr>F & MS & Pr>F & MS & Pr>F & MS & Pr>F & MS & Pr>F \\
\hline BG & 5 & 21.29 & 0.046 & 1.14 & 0.680 & 0.57 & 0.445 & 2.47 & 0.491 & 2.61 & 0.483 \\
LS & 2 & 309.83 & 0.000 & 10.64 & 0.003 & 2.42 & 0.019 & 11.37 & 0.018 & 9.89 & 0.036 \\
BG*LS & 10 & 12.32 & 0.213 & 0.68 & 0.957 & 0.67 & 0.351 & 1.12 & 0.944 & 1.31 & 0.918 \\
\hline Error & 162 & 9.20 & & 1.83 & & 0.60 & & 2.79 & & 2.91 & \\
$\mathrm{R}^{2}$ & & 0.363 & & 0.102 & & 0.129 & & 0.092 & & 0.088 & \\
\hline
\end{tabular}

$\mathrm{BG}=$ Breed group, $\mathrm{LS}=$ Lactation stage, $\mathrm{MY}=$ milk yield, $\mathrm{SNF}=$ Solids- not fat, $\mathrm{TS}=$ Total solid 
Table 2. Analysis of variance of milk quality traits

\begin{tabular}{|c|c|c|c|c|c|c|c|c|c|}
\hline \multirow{2}{*}{$\begin{array}{l}\text { Source of } \\
\text { Variation }\end{array}$} & \multirow[t]{2}{*}{ DF } & \multicolumn{2}{|c|}{$\mathrm{SG}$} & \multicolumn{2}{|c|}{$\mathrm{pH}$} & \multicolumn{2}{|c|}{ TA } & \multicolumn{2}{|c|}{ MBRT } \\
\hline & & & $\operatorname{Pr}>F$ & MS & $\operatorname{Pr}>\mathrm{F}$ & MS & $\operatorname{Pr}>F$ & MS & $\operatorname{Pr}>F$ \\
\hline $\mathrm{BG}$ & 5 & 0.000 & 0.5805 & 0.12 & 0.220 & 0.002 & 0.041 & 3.25 & 0.3796 \\
\hline LS & 2 & 0.000 & 0.0022 & 0.05 & 0.538 & 0.002 & 0.084 & 5.51 & 0.1662 \\
\hline BG*LS & 10 & 0.000 & 0.3582 & 0.10 & 0.280 & 0.001 & 0.120 & 0.90 & 0.9808 \\
\hline Error & 162 & 0.001 & & 0.08 & & 0.001 & & 3.04 & \\
\hline $\mathrm{R}^{2}$ & & 0.145 & & 0.112 & & 0.167 & & 0.068 & \\
\hline
\end{tabular}

$\mathrm{BG}=$ Breed group, $\mathrm{LS}=$ Lactation stage, $\mathrm{SG}=$ Specific gravity, $\mathrm{TA}=$ Titrable acidity, MBRT= Methylene blue reduction test

Table 3: Milk composition and milk quality traits of different breed groups

\begin{tabular}{|c|c|c|c|c|c|c|c|c|c|}
\hline \multicolumn{10}{|c|}{ Milk Composition Traits $($ mean \pm SE) } \\
\hline BG & $\begin{array}{l}\mathrm{MY} \\
(\mathrm{kg})\end{array}$ & $\begin{array}{l}\text { Fat } \\
(\%)\end{array}$ & $\begin{array}{l}\text { SNF } \\
(\%)\end{array}$ & $\begin{array}{c}\text { TS } \\
(\%)\end{array}$ & $\begin{array}{l}\mathrm{H}_{2} \mathrm{O} \\
(\%)\end{array}$ & Sp.Gr. & $\mathrm{pH}$ & $\begin{array}{l}\text { TA } \\
(\%)\end{array}$ & MBRT \\
\hline M50-1 & $\begin{array}{l}8.73^{\mathrm{a}} \\
\pm 1.65\end{array}$ & $\begin{array}{l}4.20^{\mathrm{a}} \\
\pm 0.49\end{array}$ & $\begin{array}{l}9.40^{\mathrm{a}} \\
\pm 0.38\end{array}$ & $\begin{array}{l}13.60^{\mathrm{a}} \\
\pm 0.61\end{array}$ & $\begin{array}{l}86.40^{\mathrm{a}} \\
\pm 0.62\end{array}$ & $\begin{array}{l}1.031^{\mathrm{a}} \\
\pm 0.00\end{array}$ & $\begin{array}{l}6.74^{b} \\
\pm 0.07\end{array}$ & $\begin{array}{l}0.15^{\mathrm{a}} \\
\pm 0.00\end{array}$ & $\begin{array}{l}7.00^{\mathrm{a}} \\
\pm 0.58\end{array}$ \\
\hline M50-2 & $\begin{array}{l}6.77^{\mathrm{b}} \\
\pm 0.84\end{array}$ & $\begin{array}{l}3.99^{\mathrm{a}} \\
\pm 0.30\end{array}$ & $\begin{array}{l}9.02^{\mathrm{a}} \\
\pm 0.23\end{array}$ & $\begin{array}{l}13.01^{\mathrm{a}} \\
\pm 0.39\end{array}$ & $\begin{array}{l}86.09^{\mathrm{a}} \\
\pm 0.45\end{array}$ & $\begin{array}{l}1.030^{\mathrm{a}} \\
\pm 0.00\end{array}$ & $\begin{array}{l}6.86^{\mathrm{ab}} \\
\pm 0.05\end{array}$ & $\begin{array}{l}0.13^{\mathrm{b}} \\
\pm 0.01\end{array}$ & $\begin{array}{l}7.40^{\mathrm{a}} \\
\pm 0.55\end{array}$ \\
\hline M50-3 & $\begin{array}{l}7.06^{\mathrm{ab}} \\
\pm 0.86\end{array}$ & $\begin{array}{l}4.50^{\mathrm{a}} \\
\pm 0.36\end{array}$ & $\begin{array}{l}9.31^{\mathrm{a}} \\
\pm 0.23\end{array}$ & $\begin{array}{l}13.81^{\mathrm{a}} \\
\pm 0.45\end{array}$ & $\begin{array}{l}86.19^{\mathrm{a}} \\
\pm 0.48\end{array}$ & $\begin{array}{l}1.031^{\mathrm{a}} \\
\pm 0.00\end{array}$ & $\begin{array}{l}6.79^{\mathrm{ab}} \\
\pm 0.05\end{array}$ & $\begin{array}{l}0.15^{\mathrm{a}} \\
\pm 0.01\end{array}$ & $\begin{array}{l}6.95^{\mathrm{a}} \\
\pm 0.55\end{array}$ \\
\hline M56 & $\begin{array}{l}7.06^{\mathrm{ab}} \\
\pm 0.96\end{array}$ & $\begin{array}{l}4.17^{\mathrm{a}} \\
\pm 0.46\end{array}$ & $\begin{array}{l}9.25^{\mathrm{a}} \\
\pm 0.29\end{array}$ & $\begin{array}{l}13.42^{\mathrm{a}} \\
\pm 0.56\end{array}$ & $\begin{array}{l}86.58^{\mathrm{a}} \\
\pm 0.57\end{array}$ & $\begin{array}{l}1.030^{\mathrm{a}} \\
\pm 0.00\end{array}$ & $\begin{array}{l}6.91^{\mathrm{a}} \\
\pm 0.14\end{array}$ & $\begin{array}{l}0.14^{\mathrm{ab}} \\
\pm 0.01\end{array}$ & $\begin{array}{l}6.50^{\mathrm{a}} \\
\pm 0.48\end{array}$ \\
\hline M63 & $\begin{array}{l}6.33^{\mathrm{b}} \\
\pm 0.98\end{array}$ & $\begin{array}{l}4.09^{\mathrm{a}} \\
\pm 0.43\end{array}$ & $\begin{array}{l}9.37^{\mathrm{a}} \\
\pm 0.24\end{array}$ & $\begin{array}{l}13.46^{\mathrm{a}} \\
\pm 0.54\end{array}$ & $\begin{array}{l}86.54^{\mathrm{a}} \\
\pm 0.52\end{array}$ & $\begin{array}{l}1.031^{\mathrm{a}} \\
\pm 0.00\end{array}$ & $\begin{array}{l}6.79^{\mathrm{ab}} \\
\pm 0.06\end{array}$ & $\begin{array}{l}0.14^{\mathrm{ab}} \\
\pm 0.01\end{array}$ & $\begin{array}{l}6.68^{\mathrm{a}} \\
\pm 0.45\end{array}$ \\
\hline M75-1 & $\begin{array}{l}7.70^{\mathrm{ab}} \\
\pm 0.82\end{array}$ & $\begin{array}{l}3.96^{\mathrm{a}} \\
\pm 0.42\end{array}$ & $\begin{array}{l}9.20^{\mathrm{a}} \\
\pm 0.20\end{array}$ & $\begin{array}{l}13.16^{\mathrm{a}} \\
\pm 0.44\end{array}$ & $\begin{array}{l}86.84^{\mathrm{a}} \\
\pm 0.44\end{array}$ & $\begin{array}{l}1.031^{\mathrm{a}} \\
\pm 0.00\end{array}$ & $\begin{array}{l}6.78^{\mathrm{ab}} \\
\pm 0.05\end{array}$ & $\begin{array}{l}0.13^{\mathrm{b}} \\
\pm 0.01\end{array}$ & $\begin{array}{l}7.20^{\mathrm{a}} \\
\pm 0.50\end{array}$ \\
\hline $\begin{array}{l}\text { Probabi } \\
\text { lity }\end{array}$ & $\mathrm{P}>0.001$ & NS & NS & NS & NS & NS & $\mathrm{P}>0.02$ & $\mathrm{P}>0.019$ & NS \\
\hline
\end{tabular}

Overall means for a particular parameter (column) that do not share any of the superscripts are significantly different $(P \leq 0.05)$.

$\mathrm{BG}=$ Breed group, $\mathrm{MY}=$ Milk yield, $\mathrm{SNF}=$ Solid not fat, $\mathrm{TS}=$ Total solid, $\mathrm{SG}=$ Specific gravity, $\mathrm{TA}=$ Titrable acidity, MBRT= Methylene blue reduction test. 
There was no significant difference in the mean TA of milk among M50-1 and M50-3. The milk TA of M50-2 and M75-1 were significantly $(P \leq 0.05)$ lower than M50-1 and M50-3.

The milk of the six breed groups did not differ in its fat, solid not fat (SNF), total solid (TS) and water content (H20). The quality of the milk did not differ with respect to the different breed groups. The fat content of milk in this study was $3.96-4.50 \%$, which, is within the range for milk composition standard requirement for cows of 3.5 - 5.0\% (Anantakrishnan et al., 1993). Herrinton (2000) described that the percentage of fat $(3.65-3.90 \%)$ in milk shows more variation than percentage of the other major constituents. Farrington and Woll (2010) stated that the cow's milk generally contains between 3 and 6 per cent fat. The standard adopted by US government for fat in milk is 3.25 per cent. Although, Nevens (2010) found that the fat percentage of five dairy breeds (Ayrshire, Brown Swiss, Guersey, Holstein and Jersey) were ranged from $3.41 \%$ to $5.06 \%$. Banerjee (2009) described that the fat percent of Indian dairy cattle ranged from 3.5 to $5.5 \%$.

The mean for SNF in this study (9.02 - 9.40\%) was within the recommended value of $8.5-9.5 \%$ (Anantakrishnan et al., 1993). TS content of the milk in the present study $(13.01-13.81 \%)$ met the milk composition standard requirement for cows of 12.8 - 14.5\% (Anantakrishnan et al., 1993). Although, Nevens (2010) described that the TS percentage of five dairy breeds (Ayrshire, Brown Swiss, Guersey, Holstein and Jersey) with ranged from 12.27 to $14.54 \%$. The Indian dairy cattle milk TS percent ranged from 12.20 to $15.0 \%$ as described by Banerjee (2009).

The $86.26-87.07 \%$ water content observed in the milk of the present study met the milk composition standard requirement for cows (84 to 88\%) (Anantakrishnan et al., 1993). Herrinton (2000) described that the percentage of water content of milk ranged from 87.20 to $87.90 \%$. Farrington and Woll (2010) stated that the water content of normal American cow's milk ranged from 82 to $90 \%$. Although, Nevens (2010) found that the $\mathrm{H}_{2} \mathrm{O}$ percentage of five dairy breeds (Ayrshire, Brown Swiss, Guersey, Holstein and Jersey) ranged from 85.37 to $87.73 \%$. The breed groups influences milk composition; when MY increases, the $\mathrm{H}_{2} \mathrm{O}$ decreases. Animals belonging to the same breed group and maintained under uniform environmental conditions have been found to milk different composition (Anantakrishnan et al., 1993). The variation in MY and $\mathrm{H}_{2} \mathrm{O}$ may be due to differences in composition of milk of individual animals.

For the milk quality traits, the milk Sp.Gr. was $1.030-1.031$ for all breed groups which met the standard requirement for cow milk (1.028 1.032) (Anantakrishnan et al., 1993). TA of milk did not differ significantly $(P>0.05)$ among M50-1, M50-3, M56 and M63. TA of milk for M50-2 and M75-1 was significantly $(P \leq 0.05)$ different from that of M50-1 and M50-3. The mean TA value for the breed group ranged between 0.13 to 0.15 . The natural acidity of fresh milk is within 0.13 to $0.21 \%$ (Anantakrishnan et al., 1993). The TA of milk in the present study met the required standard. The amount of phosphates, proteins, citrates and dissolved carbon dioxide in milk vary with breed groups and in turn affect the acidic nature of milk. The $\mathrm{pH}$ of milk in this study was significantly different among breed group. The highest $\mathrm{pH}$ was in M56 group and was the lowest in M50-1 group and the ranged was $6.74-6.91$. Anantakrishnan et al. (1993) suggested that if the $\mathrm{pH}$ value of milk was $6.5-6.7$, then the milk sample might be conferred free from mastitis or bacterial contamination.

The average mean of Methylene blue reduction test (MBRT) for the breed groups was 6.50 to 7.20 hour. Anantakrishnan et al. (1993) recommended that standard decolourization rate of milk was 5 hours and Devids (1999) studied that decolourization rate of milk May to October 4.5 hour and November to April 5.5 hours. Higher MBRT value of the studies suggests that bactological condition of milk was very less. The grade of milk of these studies was good. 


\subsection{Stage of lactation}

Lactation stage had a significant $(P \leq 0.05)$ effect on MY, fat, SNF, TS, $\mathrm{H}_{2} 0$, TA and SG (Table 4). The means of milk constituents and quality traits at the different stages of lactation (early, middle and late) are shown in Table 4. MY was decreased, significantly $(P \leq 0.01)$ with lactations stage. Nevens (2010) described that the daily milk yield and to some extent also percentage of butter fat in the milk are profoundly affected the stage of lactation. The milk produced by an animal does not follow a constant trend throughout the lactation period. The milk production for a mature cow generally increases rapidly after parturition, reaches a peak at around 90 day and then declines linearly (Wood, 1967; Schimidt, 1971; Kellogg et al., 1977).

Fat\% of early lactation was significantly $(P \leq 0.01)$ lower than middle and late lactations (3.69, 4.27 and 4.50 , respectively). It might be due to the fact that fat and milk yield are inversely correlated. As milk yield increases fat percentage decreases. Banard et al. (1970) reported that approximately 10 weeks after calving fat concentration in the milk increased until the end of the lactation.

Late and early lactation milk SNF was significantly $(P \leq 0.05)$ higher than SNF at middle lactation. Anantakrishnan et al. (1993) recommended that there is decrease in SNF content from the time animal pastorates until about 15 days when it is stabilized except during the last three months when there is continuous increase SNF\%. Most literatures suggest that there is no increase in the SNF percentages of milk during the later part of lactation if the cows are not pregnant (Rook et al., 1965; Spike et al., 1967).

There was no significant $(P>0.05)$ different ness of specific gravity of milk in the stage of lactation. The ranges of specific gravity of milk in the stage of lactation was 1.030 to 1.031 . Milk normally varies in specific gravity between 1.028 to 1.034. Anantakrishnan et al. (1993) reported that generally the specific gravity of cow's milk ranges from 1.028 to 1.032 . The specific gravity of these studies required standard. TS content of late lactation of milk was significantly $(P \leq 0.05)$ higher than milk of early lactation. Fat and SNF are the components in TS. These two components of milk increased in the late lactation and so TS also increased.

Water content of early lactation was significantly $(P \leq 0.05)$ higher than that of late lactation. Water actually followed the similar trend as MY over the lactation stages. Early lactation TA was significantly $(P \leq 0.05)$ higher $(0.145)$ than middle and late lactations.

Table 4. Effect of stage of lactation on milk quality of different breed groups.

\begin{tabular}{llll}
\hline \multirow{2}{*}{ Traits } & \multicolumn{3}{c}{ Stage of lactation } \\
\cline { 2 - 4 } & Early & \multicolumn{1}{c}{ Middle } & Late \\
\hline MY $(\mathrm{kg})$ & $9.68^{\mathrm{a}} \pm 0.70$ & $6.99^{\mathrm{b}} \pm 0.36$ & $5.16^{\mathrm{c}} \pm 0.36$ \\
Fat $(\%)$ & $3.69^{\mathrm{b}} \pm 0.07$ & $4.27^{\mathrm{a}} \pm 0.12$ & $4.50^{\mathrm{a}} \pm 0.15$ \\
SNF $(\%)$ & $9.37^{\mathrm{a}} \pm 0.06$ & $9.03^{\mathrm{b}} \pm 0.14$ & $9.38^{\mathrm{a}} \pm 0.09$ \\
TS (\%) & $13.05^{\mathrm{b}} \pm 0.09$ & $13.30^{\mathrm{a}} \pm 0.15$ & $13.90 \pm 0.22$ \\
H20 (\%) & $87.47^{\mathrm{a}} \pm 0.51$ & $86.66^{\mathrm{ab}} \pm 0.17$ & $86.16^{\mathrm{b} \pm 0.22}$ \\
Sp.Gr. & $1.031^{\mathrm{a}} \pm 0.0$ & $1.030^{\mathrm{a}} \pm 0.0$ & $1.031^{\mathrm{a} \pm 0.0}$ \\
PH & $6.78^{\mathrm{a}} \pm 0.06$ & $6.82^{\mathrm{a}} \pm 0.03$ & $6.84^{\mathrm{a}} \pm 0.02$ \\
TA & $0.145^{\mathrm{a}} \pm 0.0$ & $0.133^{\mathrm{b}} \pm 0.0$ & $0.137^{\mathrm{ab}} \pm 0.0$ \\
MBRT & $6.61^{\mathrm{a} \pm 0.20}$ & $7.17^{\mathrm{a}} \pm 0.14$ & $7.09^{\mathrm{a}} \pm 0.15$ \\
\hline
\end{tabular}

Means for particular parameter (row) that do not share any superscripts are significantly different $(P \leq 0.05)$ 


\subsection{Correlation among milk composition traits} Correlations among the milk composition and quality traits for the six Sahiwal - Friesian crossbreed groups are presented in Table 5. Generally, none of the milk composition traits was correlated with MY. Fat and TS generally, had significant $(P \leq 0.05)$ negative correlation with $\mathrm{H}_{2} \mathrm{O}$ content for all breed groups. TS and TA was significantly $(P \leq 0.05)$ correlated with fat and SNF. The rest of the milk composition traits did not show any consistent significant correlation, with respect to breed groups.

TS and SNF were positively correlated. Kaushik and Tandan (1979) and Darsal Lal and Narayanan (1990) found that TS and SNF was positively correlated. Milk fat and TS content, generally, had significant $(P \leq 0.05)$, negative correlation with $\mathrm{H}_{2} \mathrm{O}$ content of milk for all breed groups for the three lactation stages. It indicates that $\mathrm{H}_{2} \mathrm{O}$ is correlated in an inversely with fat and TS. In the present study, fat and TS showed positive $(P \leq 0.05)$ correlation in all lactation stages. Similar result was reported by Darshan Lal and Narayanan (1990) in milk of cows and
Murrah buffaloes. Kaushik and Tandan (1979), however, found that fat and TS were negatively correlated in Hariana cattle. The variation may be due to milk samples being collected from different breed groups and farms and also management practices were different.

\section{Conclusions}

The optimum level of Friesian inheritance in combination with Sahiwal for MY appear to be $75 \%, 56 \%$ and $50 \%$ with selection for milk production. Therefore, the qualities of milk from the Sahiwal - Friesian crossbred cows met the required standard. It was revealed that the Sahiwal - Friesian crossbred animal was the best performer regarding the milk composition and quality.

\section{Acknowledgements}

The authors would like to acknowledg the Department of Veterinary Services, Ministry of Agriculture, Malaysia and staff of the Ladang Pusat Ternakan Haiwan Ayer Hitam, Johor for their assistance in making this study possible.

Table 5. Correlations analysis of milk composition traits. (Pearsons correlation coefficients)

\begin{tabular}{llllllllll}
\hline & FAT & SNF & TS & SG & PH & TA & MBRT & MY & H20 \\
\hline FAT & 1.000 & & & & & & & & \\
SNF & $0.152^{*}$ & 1.000 & & & & & & & \\
& 0.041 & & & & & & & & \\
TS & $0.885^{* *}$ & $0.593^{* *}$ & 1.000 & & & & & & \\
& 0.000 & 0.000 & & & & & & & \\
SG & $-.0 .243^{* *}$ & $0.901^{* *}$ & $0.230^{* *}$ & 1.000 & & & & & \\
& 0.001 & 0.000 & 0.002 & & & & & & \\
PH & $-0.149^{*}$ & -0.035 & -0.136 & 0.008 & 1.000 & & & & \\
& 0.045 & 0.637 & 0.068 & 0.920 & & & & & \\
TA & $0.207^{*}$ & $0.235^{*}$ & $0.278^{* *}$ & 0.140 & $-0.187^{*}$ & 1.000 & & & \\
& 0.005 & 0.002 & 0.000 & 0.061 & 0.012 & & & & \\
MBRT & -0.071 & 0.001 & -0.055 & 0.039 & $0.206^{* *}$ & $-0.255^{* *}$ & 1.000 & & \\
& 0.347 & 0.990 & 0.465 & 0.608 & 0.006 & 0.001 & & & \\
MY & -0.103 & 0.080 & -0.047 & 0.126 & -0.121 & 0.075 & -0.142 & 1.000 & \\
& 0.168 & 0.285 & 0.535 & 0.091 & 0.107 & 0.320 & 0.058 & & \\
H20 & $-0.866^{* *}$ & $0-.599^{* *}$ & $0-.987^{* *}$ & $-0.244^{* *}$ & 0.142 & $-.0 .243^{* *}$ & 0.059 & 0.035 & 1.000 \\
& 0.000 & 0.000 & 0.000 & 0.001 & 0.058 & 0.001 & 0.429 & 0.638 & \\
\hline
\end{tabular}

Upper value 1, $\mathrm{n}=180, \mathrm{MY}=$ Milk yield, $\mathrm{SNF}=$ Solid not fat, TS = Total solid, SG = Specific gravity, TA= Titrable acidity, MBRT= Methylene blue reduction test. 


\section{References}

Anantakrishnan, C. P., Khan, A. Q. and Padmanabhan, P. N. 1993. The Technology of Milk Processing, Shri Lakshmi Publications, Kilpauk, Madras, 1-25 pp.

Barnard, C., Halley, S. and Scott, A. H. 1970. Variations in milk yield and milk quality, Milk Production, Published, Life books Ltd. London. 200-214 pp.

Banerjee, G. C. 2009. A text book of Animal Husbandry. Eighth Edition, Oxford \& IBH Publishing Co. Pvt. Ltd., New Delhi, $695 \mathrm{p}$.

Darshan Lal and Narayanan, K. M. 1990. A correlation study between milk composition and yield with lactation number and stage of lactation. Indian Journal of Animal Sciences, 60(6):735$737 \mathrm{pp}$.

Devis, J. G. 1999. Milk testing (Bacteriological tests). The laboratory control of milk. Agro Batanical Publisher, 4E J. N Vgas Nagar, Bikanar, India, 145-153 pp.

DVS. 1998. Annual report, Livestock production and per capita consumption of livestock products. Department of Veterinary Services. Ministry of Agriculture, Malaysia.

Everett, H. and Segun, O. 1985. Anatomy and Physiology of Tropical Livestock, 119$120 \mathrm{pp}$

Farrington, E. H. and Woll, F. W. 2010. Testing milk and its products. Published by Axis books (India). 10-Vyas Ji Ka Nohra Sardar para. India, 10-13 pp.

Herrinton, B. L. 2000. Milk and milk processing. Published by Greenworld Publishers, 8/217 Indira Nagar, Lucknow-226016 (UP).

IHK. 1999. Annual report, temperature, rainfall and humidity. Institute Haiwan Kluang Johor, Malaysia.

Kaushik, S. N. and Tandon, O. B. 1979. Influence of various genetic and non genetic factors on important milk component traits in Hariana cattle. Indian Journal of Animal Science, 49 (5): 327331.

Kellogg, W. D., Scott Urquhart, N. and Ortega, A. J. 1977. Estimating Holstein lactation curves with gamma curve. Journal of Dairy Science, 60: 1308-1315.

Nevens, W. B. 2010. Principles of milk production. Published by Axis books, 10Vyas Ji Ka Nohra Sardar para, India, 256$259 \mathrm{pp}$.

Osman, A. 1993. Dairy Production. Animal Industry in Malaysia: Paper presented Faculty of Veterinary Medecine \& Animal Sciences, Universiti Pertanian Malaysia, Serdang, Selangor, Malaysia. 41-49 pp.

Ramond, A. K. and Ratna Kumar, D. 1997. Proc. Of Expert Discussion in Breeding programmes for Ruminants in Asia. Kandalama, Sri lanka, 31 March - 4 April, 1997, 77-91 pp.

Rook, J. A. F. and Campling, R. C. 1965. Journal of Dairy Research: 32-45. (Cited from Schimidt, 1971, Biology of lactation, 178-198 pp).

Schmidt, G. H. 1971. Factors Affecting the yield and composition of milk. Biology of lactation. $178-198 \mathrm{pp}$.

Spike, P. W. and Freman, A. E. 1967. Factors affecting the yield and composition of milk. Journal of Dairy Science, 50: 1897.

Sivarajasingam, S., Yusoff, S., Mohamad, N. G., Sivasupramaniam, G., Abas, M. O. and Eusof, J. 1982. Dairy cattle Production in Peninsular Malaysia. Proceeding Conference. Malaysian Livestock Industries; Status and Potential, Genting Highlands, Malaysia, 37- 87 pp.

Sivarajasingam, S. and Kumar, A. R. 1993. Comparative performances of Malaysian, Australian, and New Zealand F1 Friesian crossbreds. Livestock Production Science, 36: 299-310.

Wood, P. D. P. 1967. Algebraic model of the lactation curve in cattle. Nature, Lond. 216: 164- 165 . 